\title{
How Do Markets React to Tighter Bank Capital Requirements?
}

\author{
Cyril Couaillier ${ }^{1}$ and Dorian Henricot ${ }^{2}$
}

\author{
June 2020, WP \#772
}

\begin{abstract}
We use hikes in the countercyclical capital buffer [CCyB] to measure how tighter bank capital requirements affect their solvency and value, according to market participants. Two features of the $\mathrm{CCyB}$ in Europe allow for a unique identification strategy of the effect of such requirements. First, national authorities make quarterly announcements of CCyB rates. Second, these hikes affect all European banks proportionally to their exposure to the country of activation. We show that CCyB hikes translate in lower CDS spreads for affected banks, indicating that markets perceive higher solvency. On the other hand, bank valuations do not react. Markets therefore consider that higher capital requirements translate into more stable banks at no material cost for shareholders. We claim that these effects relate to the capital constraint itself, as opposed to the potential signal conveyed on the state of the financial cycle.
\end{abstract}

Keywords: Event Studies, Banking, Capital Requirements,

JEL classification: G14, G21, G28

${ }^{1}$ Banque de France, Sciences Po Paris, cyril.couaillier@ecb.europa.eu

${ }^{2}$ Banque de France, Sciences Po Paris, dorian.henricot@banque-france.fr

We thank David Aikman, Nicolas Coeurdacier, Stéphane Guibaud, Guillaume Plantin, René Stulz and Mirko Wiederholt, as well as participants to seminars at the Banque de France and SciencesPo Paris for their useful comments and suggestions. We are also grateful to the LSE's Systemic Risk Center for helping us with data access. We are also thankful to the whole Macroprudential Policy team of the Banque de France for their support, and to the PGCR for their help with data collection and analysis. The views expressed herein are those of the authors and do not necessarily reflect those of the Banque de France and the Eurosystem.

Working Papers reflect the opinions of the authors and do not necessarily express the views of the Banque de France. This document is available on publications.banque-france.fr/en 


\section{NON-TECHNICAL SUMMARY}

The 2008 financial crisis has highlighted the need for sufficient bank capital, as banking crises and their companion credit crunches are particularly damaging to the real economy. Consequently, the main regulatory response to the crisis has been a large increase in capital requirements. In doing so, it is key for regulators to strike the appropriate balance between the benefits of more stable banks and the cost of more expensive capital.

Unfortunately, it is difficult to assess the actual impact of higher capital requirements. First, they often result from years of negotiation, which dilutes their impact over time. Second, since regulators usually impose similar requirements on all banks, it is difficult to study the differential impact of capital requirements across banks. In this study, we use the institutional setup of the so-called countercyclical capital buffer (hereafter $\mathrm{C} C \mathrm{~B} B$ ) in the European Economic Area (hereafter EEA) to overcome those challenges.

The countercyclical capital buffer is a time-varying capital requirement introduced in Basel III and designed to tackle the procyclicality of bank credit. The CCyB offers two distinctive features to overcome the aforementioned difficulties. First, national authorities choose $\mathrm{CCyB}$ rates on a quarterly basis. Second, the $\mathrm{C} C \mathrm{BB}$ rate in a given country applies to all banks of the EEA, proportionally to the share of that country in their total relevant exposures.

We leverage this framework to feed the debate on the costs and benefits of capital requirements: do they enhance bank resilience, and at which cost for shareholders? In theory, $\mathrm{CCyB}$ increases could trigger market reactions through two channels. First, they reveal private information that the national regulator may hold on the state of the economy. Macroprudential authorities typically raise the $\mathrm{CCyB}$ when the economy is in good shape, but also when financial risks are building up. We label this the signalling channel. The second channel relates to the requirement itself, which tightens the capital constraint and forces banks to hold more capital. We label this the capital channel. It is important to disentangle both channels, since the capital channel alone captures the structural impact of higher capital requirements.

We proceed in three steps. We first investigate how country-level $\mathrm{CCyB}$ decisions affect country-level stock index and sovereign credit default swap markets (hereafter CDS). We find that country-level variables do not systematically react to country-level CCyB increases, which suggests that $\mathrm{C} C \mathrm{~B}$ announcements do not systematically convey a signal on the state of the economy. Any impact on banks' securities is thus attributable to the capital channel. Then, we show that a 1-percentage point bank-level CCyB increase translates in a 13 basis points decrease in that bank's CDS spread within three days from the announcement - or an $18 \%$ decrease in CDS spread level. As such, financial markets believe that higher capital requirements lower banks' probability of default, and factor this into lower CDS spreads. Finally, we find that bank-specific CCyB increases are not associated with any stock return regularity. This result suggests that shareholders do not believe this additional resilience comes at any cost for them.

These results are important to understand the costs and benefits of capital requirements. They show that a modest increase in capital requirements can strengthen banks at no cost for shareholders. Consequently, regulators may have further room to tighten capital requirements without triggering a negative market reaction. In future research, it will be interesting to exploit this setup to understand how capital requirements affect lending, and how CCyB releases may asymmetrically affect financial markets. 


\section{Mean cumulated abnormal change in CDS spreads around announcements of CCyB hikes}

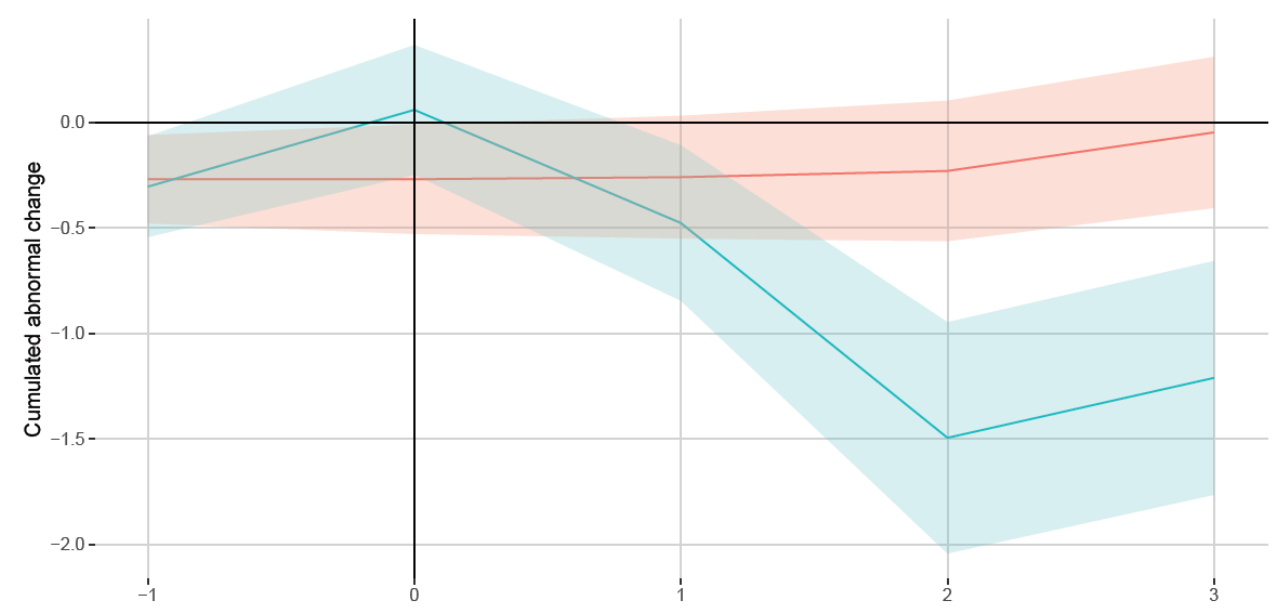

Notes: Green (red) line indicates the cumulated abnormal change in CDS spread for (un)affected banks, in basis points. (Un)affected banks are banks receiving a strictly positive (null) CCyB shock on announcement days. Each $\mathrm{CCyB}$ hike affects between 1 and 23 banks, out of 27 banks in our panel. The $\mathrm{x}$-axis represents the number of days from the announcement day, which is marked as 0 . Shaded areas correspond to $+/-1$ standard error. $\mathrm{CCyB}$ announcements with overlapping event windows are excluded.

Sources: ESRB, Eikon, Bloomberg, Markit, Authors' calculations.

\section{Comment réagissent les marchés à un resserrement des exigences en capital bancaire?}

\section{RÉSUMÉ}

Nous utilisons les hausses de coussin contracyclique $[\mathrm{CCyB}]$ pour mesurer l'impact d'un resserrement des exigences en capital bancaire sur la valorisation et la solvabilité d'une banque, du point de vue des investisseurs. Deux caractéristiques du CCyB en Europe nous permettent d'effectuer une estimation originale. D'une part, les hausses de CCyB sont décidées trimestriellement dans chaque pays. D'autre part, ces hausses affectent toutes les banques européennes, à proportion de leurs expositions aux pays d'activation. Nous montrons que les hausses de $\mathrm{C} C \mathrm{yB}$ entrainent une baisse des primes de CDS des banques affectées, tandis que leurs valorisations boursières restent constantes. Les marchés semblent donc apprécier la hausse de la solvabilité bancaire due à ces exigences, tout en estimant qu'elles ne seront pas coûteuses pour les actionnaires. Nous attribuons ces résultats à la hausse de la contrainte en capital plutôt qu'à un effet de signal sur l'état du cycle financier.

Mots-clés : études d'événement, banques, exigences en capital

Les Documents de travail reflètent les idées personnelles de leurs auteurs et n'expriment pas nécessairement la position de la Banque de France. Ils sont disponibles sur publications.banque-france.fr 


\section{Introduction}

The Great Financial Crisis (hereafter GFC) has highlighted the need for sufficient bank capital, as banking crises and their companion credit crunches are particularly damaging to the real economy. Consequently, the main regulatory response to the GFC has consisted in a large increase in bank capital requirements. The banking industry usually opposes high capital requirements, arguing that they impose undue charge to banks in the form of higher cost of capital. As such, it is key for regulators to strike the appropriate balance between the benefits of more stable banks and the costs of more expensive capital. Unfortunately, it is difficult to assess the actual impact of higher capital requirements. First, they often result from years of negotiation and are largely anticipated. Second, they are generally common to all banks in a given region, making it difficult to disentangle their effect from other market-wide events.

In this study, we use the institutional setup of the so-called countercyclical capital buffer (hereafter $\mathrm{CCyB}$ ) in the European Economic Area (hereafter EEA) to overcome those challenges. Indeed the $\mathrm{CCyB}$, a time-varying bank capital requirement introduced in Basel III and adapted in European regulation, offers two attractive features for such study. To start with, CCyB levels are decided quarterly at a country-level, with press releases allowing for an exact identification of the announcement date. $\mathrm{CCyB}$ are announced independently of other decisions. The time-varying effect of these quarterly shocks allows to perform within-bank shock identification. Then, the $\mathrm{CCyB}$ rate in a given country applies to all banks of the EEA, proportionally to the share of that country in their total (relevant) exposures. Consequently, each shock heterogeneously impacts all banks of the EEA, allowing for cross-sectional studies. Thanks to those two features, we use CCyB announcements in an event study framework to assess how financial markets perceive the costs and benefits of higher capital requirements. To do so, we investigate whether those announcements translate into lower bank CDS spreads - suggesting a fall in their credit risk, and into lower stock returns - suggesting costly implementation. This setup allows us to make the first direct empirical estimation of the impact of capital requirements on financial markets.

$\mathrm{CCyB}$ increases can trigger market reactions through two channels. First, they reveal private information that the national regulator may hold on the state of the economy when setting the $\mathrm{CCyB}$ rate. Macroprudential authorities typically raise the $\mathrm{CCyB}$ when the economy is in good shape, but also when financial risks are building up. We label this the signalling channel. The second channel relates to the requirement itself, that tightens the capital constraint, potentially forcing banks to hold more capital. We label this the capital channel. Disentangling both channels is key to appropriately interpret results in terms of cost-benefit analysis. The capital channel alone captures the structural impact of higher capital requirements. 
We proceed in three steps.

First, we investigate the impact of $\mathrm{CCyB}$ hikes on country-level variables, namely stock indexes and sovereign CDS. We find no significant impact: country-level variables do not systematically react to country-level CCyB increases. This is inconsistent with the signalling channel and suggests that any impact is likely to transit through the capital channel.

Second, we show that CCyB increases are associated with a 13 bp decline in the CDS spreads of affected banks. This means that financial markets factor a lower probability of default in $\mathrm{CDS}$ spreads following $\mathrm{CCyB}$ hikes. In other terms, they perceive higher capital requirements as making banks more solvent.

Finally, we find that bank-specific CCyB increases are not associated with any stock return regularity. This, in conjunction with the decline in CDS spreads, is again inconsistent with the signalling channel: good economics news lowering CDS spreads should also increase stock value. This confirms the activation of the capital channel, but in a way that has no significant impact on stock prices.

Our paper contributes to the debate on the costs and benefits of capital requirements.

First, a large literature assesses the impact of capital requirements on economic activity. Among others, Fraisse et al. (2019) show that banks price higher capital requirements in their lending rates. Mésonnier \& Monks (2015) show that unanticipated hikes in capital requirements may translate in lower lending. Investigating the Swiss sectoral CCyB, Auer \& Ongena (2016) show that capital requirements targeted to a specific asset class (residential lending) lead to higher credit growth in a neighboring class (commercial lending) by the most affected banks. Using the specific dynamic provisioning system used in Spain in the 2000s, similar in spirit to the CCyB, Jimenez et al. (2017) show that banks relatively more exposed to dynamic provisioning maintained lending more throughout the GFC, with strong positive impact for their borrowers. Other papers resort to structural models to estimate ex ante the macroeconomic impact of capital requirements, as in Repullo \& Suarez (2012), Clerc et al. (2015). Our paper brings a complementary view with a direct empirical assessment of market participants' perception of requirements.

A second strand of the literature deals with the on the impact of capital requirements on market valuations. Stress testing exercises have been used to measure the impact of capital requirements. In these exercises, regulators simulate episodes of financial stress to identify under-capitalized banks, whose capital requirements may subsequently be tightened. The 2011-12 European Banking Authority (hereafter EBA) stress tests (Mésonnier \& Monks (2015)), as well as the stress tests preceding the launch of the Banking Union in Europe in 2013-14 (Carboni et al. (2017)) entailed negative abnormal stock returns for the weakest banks. Moreover, Mésonnier \& Monks (2015) showed that banks with higher capital shortfalls experienced CDS spread increases following announcements: stress tests 
revealed the fragility of some banks to market participants. Indeed, stress tests differ widely in their setups and convey lots of private information at the bank-level (Morgan et al. (2014), Petrella \& Resti (2013)), since one of their objective is to increase market transparency. Therefore event studies of specific stress tests do not capture the mere effect of capital requirements. Conversely, the $\mathrm{CCyB}$ setup provides a stable regulatory environment to study capital requirement hikes across multiple announcements. Another series of papers investigates the differentiated impact of regulatory-induced and managers-induced bank capital issuances. Using Japanese data, Cornett \& Tehranian (1994) show that regulatory-induced capital issuances trigger weaker negative abnormal returns that voluntary issuances. This is consistent with the latter conveying more private information on possible stock overpricing. By the same token, Elyasiani et al. (2014) show that investors positively valued announcements of TARP capital injections, while they negatively receive private seasoned equity offerings. Our results are consistent with these findings: regulatory-driven increase in capital ratios do not entail any drop in stock returns. Finally, some papers focus on the impact of actual leverage on CDS spreads and show that lower leverage is associated with lower CDS spreads (Benbouzid et al. (2017), Annaert et al. (2013)).

To the best of our knowledge, our setup allows us to make the first direct empirical estimation of the impact of capital requirements on financial markets.

The rest of the paper is organized as follow. Section 2 presents the European CCyB framework, Section 3 the empirical strategy and Section 4 the data. Results are housed in Section 5. Section 6 concludes.

\section{The CCyB framework}

The CCyB is a time-varying bank capital requirement introduced with Basel III agreements. It is designed to tackle the procyclicality of bank credit. As explained by the European Systemic Risk Board (ESRB (2014)):

The countercyclical capital buffer is designed to help counter pro-cyclicality in the financial system. Capital should be accumulated when cyclical systemic risk is increasing, creating buffers that increase the resilience of the banking sector during periods of stress when losses materialise. This will help maintain the supply of credit and dampen the downswing of the financial cycle. The countercyclical capital buffer can also help dampen excessive credit growth during the upswing of the financial cycle.

The CCyB has thus two, ranked, objectives: first, improving the resilience of the banking system during financial crises; second, leaning against excessive growth of credit in the upward phase of the financial cycle. Its mechanism is the following. In a boom, 
authorities raise the $\mathrm{CCyB}$, potentially forcing banks to hold more capital. Because it occurs during an expansion, when profits and asset prices are high, banks can easily retain earnings or issue capital at low cost. Moreover, banks are given time to adjust (in practice one year), allowing them to flexibly optimize the timing and nature of the capital increase. When the bust occurs, the CCyB is released, allowing banks to absorb losses without having to cut on lending or their solvency being questioned. The objective is to prevent credit crunches, particularly damaging in crisis time. Contrary to a hike, a release of the $\mathrm{CCyB}$ is instantaneous. As a secondary effect, hikes in the $\mathrm{CCyB}$ during the upward phase may also limit the excessive build-up of debt that may sow the seed of the next financial crisis.

The CCyB is expressed in percentage of risk-weighted assets (hereafter RWA) and capital is to be held in the form of common equity tier 1 capital (hereafter CET1) - the purest form of capital, mainly consisting of retained earnings and equity issuance.

Capital requirements are usually defined by national regulatory authorities as an equal top-up for all their domestic banks. On the contrary, to ensure that banks are sufficiently capitalized relative to their geographic exposures, each national authority must determine a $\mathrm{CCyB}$ rate for exposures to all countries in the world. The delay before the entry into force must not exceed one year after the publication of the decision, and can be shorter only under exceptional circumstances. Then, each bank domiciled in country $d$ must compute a specific $\mathrm{CCyB}$ rate, defined as the average of country-level $\mathrm{CCyB}$ rates fixed by the authority of country $d$, weighted by the bank's capital requirement due to relevant risk-weighted exposure to each country. Relevant exposures include all exposures to the non-financial private sector. The bank-specific $\mathrm{CCyB}$ rate can thus be expressed as follows:

$$
C C y B_{b, d, t}=\sum_{c=1}^{N}\left\{C C \tilde{y} B_{d, c, t} * \frac{\text { Requirement }_{b, c, t}^{R W \text { Arelevant }}}{\sum_{k=1}^{N} \text { Requirement }_{b, k, t}^{R W \text { Arelevant }}}\right\}
$$

With $b$ the bank, $t$ the date, $d$ the domestic country and $c$ in $1, \ldots, N$ the countries. $C C \tilde{y} B_{d, c, t}$ is the CCyB rate applying to banks domiciled in country $d$ for their exposures in country $c$.

To avoid distortion to the level playing field, the Basel III rules include a reciprocity framework, according to which national authorities should apply to their domestic banks the rate decided in each of the participating countries for its banks' domestic exposures, so that $C C \tilde{y} B_{d, c, t}=C C \tilde{y} B_{c, t}$. National authorities have one year after the publication of a new $\mathrm{CCyB}$ rate by a foreign authority to apply it on the banks they supervise. This reciprocity applies up to a $\mathrm{CCyB}$ rate of $2.5 \%$. Above, the reciprocity is purely voluntary. If some countries do not implement any $\mathrm{CCyB}$ (for instance if it is not part of the Basel III agreements), national authorities of participating countries are free to set any $\mathrm{CCyB}$ rate $C C y B_{d, c, t}$ on this country for their banks. This has never occurred so far, meaning 
that implicitly $C C \tilde{y} B_{d, c, t}=0$ for all countries $d$ in the Basel Group and all countries $c$ outside it.

The $\mathrm{CCyB}$ was included in the European regulatory financial framework via the EEA relevant Capital Requirements Directive IV ${ }^{1}$ (hereafter CRD IV), adopted in 2013 and then transposed into national laws. CRD IV formalizes the capital regulations introduced in Basel III agreements, among which the CCyB.

This directive strengthens the reciprocity framework, making it automatic without need for domestic authorities to formally reciprocate foreign rates: up to $2.5 \%$, banks must automatically apply the $\mathrm{CCyB}$ rate set by national authorities (inside and outside the EEA) on their own country ${ }^{2}$. Above 2.5\%, the reciprocity remains voluntary. Moreover, designated authorities in the EEA can decide to apply higher $\mathrm{CCyB}$ rates on exposures to a given non-EEA country if it deems its current $\mathrm{CCyB}$ insufficient. In practice, no $\mathrm{CCyB}$ rate has so far exceeded $2.5 \%$ and no designated authority in the EEA has decided to top-up non-EEA CCyB rates. Consequently, the $\mathrm{CCyB}$ rate that applies to an EEA bank b exposed to $\mathrm{N}$ countries c, and up to $2.5 \%$, is:

$$
C C y B_{b, t}=\sum_{c=1}^{N}\left\{C C y B_{c, t} * \frac{\text { Requirement }_{b, c, t}^{R W \text { Arelevant }}}{\sum_{k=1}^{N} \text { Requirement }_{b, k, t}^{R W \text { Arelevant }}}\right\}
$$

As a result, each country-level $\mathrm{CCyB}$ announcement automatically results in an heterogeneous effect on all banks of the EEA, proportional to their relevant exposures to the activating country.

The $\mathrm{CCyB}$ is set on a quarterly basis by national authorities (the so-called designated authorities) in an institutional setup to be decided nationally. In some cases, a distinct macroprudential authority is in charge of making $\mathrm{CCyB}$ recommendations to the designated authority.

Upon decision, designated authorities must publish the rate along with an explanation for their decision. This feature will allow us to identify exact announcement days by relevant authorities. They must follow the principle of guided discretion: they are free to set the $\mathrm{CCyB}$ rate, but must rely on quantitative indicators to ground their decision. In particular, each authority has to compute on a quarterly basis a buffer guide, based on the deviation of the credit-to-GDP ratio from its long-term trend. As a result, there is no risk of reverse causality between financial events occurring on the day of the announcement and $\mathrm{CCyB}$ increases. Another concern may arise: since authorities base their decision

\footnotetext{
${ }^{1}$ Articles 130, 135, 136, 140 of Directive 2013/36/EU of the European Parliament and of the Council of 26 June 2013: https://eur-lex. europa. eu/legal-content/EN/TXT/HTML/?uri=CELEX:32013L0036\& from $=F R$

${ }^{2}$ The rule for implementation delays for EEA banks differs between EEA and non-EEA rates. For the former, the implementation delay is the one decided by the designated authority setting the rate. For countries outside the EEA, the implementation date of the reciprocity is one year after the announcement of the new rate by the foreign state, whatever its domestic implementation delay. Nevertheless, all countries have so far used a one-year implementation delay, making the difference irrelevant.
} 
partly on a quantitative metric, could shocks be anticipated? The mere existence of a systematic market reaction shows that shocks are at least not fully anticipated. However, shocks could be partly anticipated which means our measure remains a conservative assessment of the real impact of capital requirements.

In the European stacking order of capital requirements, the $\mathrm{CCyB}$ enters the so-called Combined Buffer Requirement (hereafter CBR), along with the Capital Conservation Buffer, the Systemic Risk Buffer, the Global Systemically Important Institution buffer and the Other Systemically Important Institution buffer ${ }^{3}$. In the stacking order, the CBR is above the Pillar 1 and the Pillar 2 Requirement but below the Pillar 2 Guidance (Figure 1). The breach of the CBR by a bank has two consequences. First, the bank is restricted in the amount of capital it can distribute in dividend and share buyback, by the so-called Maximum Distributable Amount (hereafter MDA) ${ }^{4}$. Second, the bank has to present a Capital Conservation Plan, including profit forecasts and intended measures to bridge the gap in capital. If the supervisor rejects the plan, it can require the institution to increase capital in a specified period and consequently lower the MDA ${ }^{5}$. Dividend restrictions and the negative ensuing signal ensure banks have incentives to comply with the $\mathrm{CCyB}$ and even keep a buffer above the CBR.

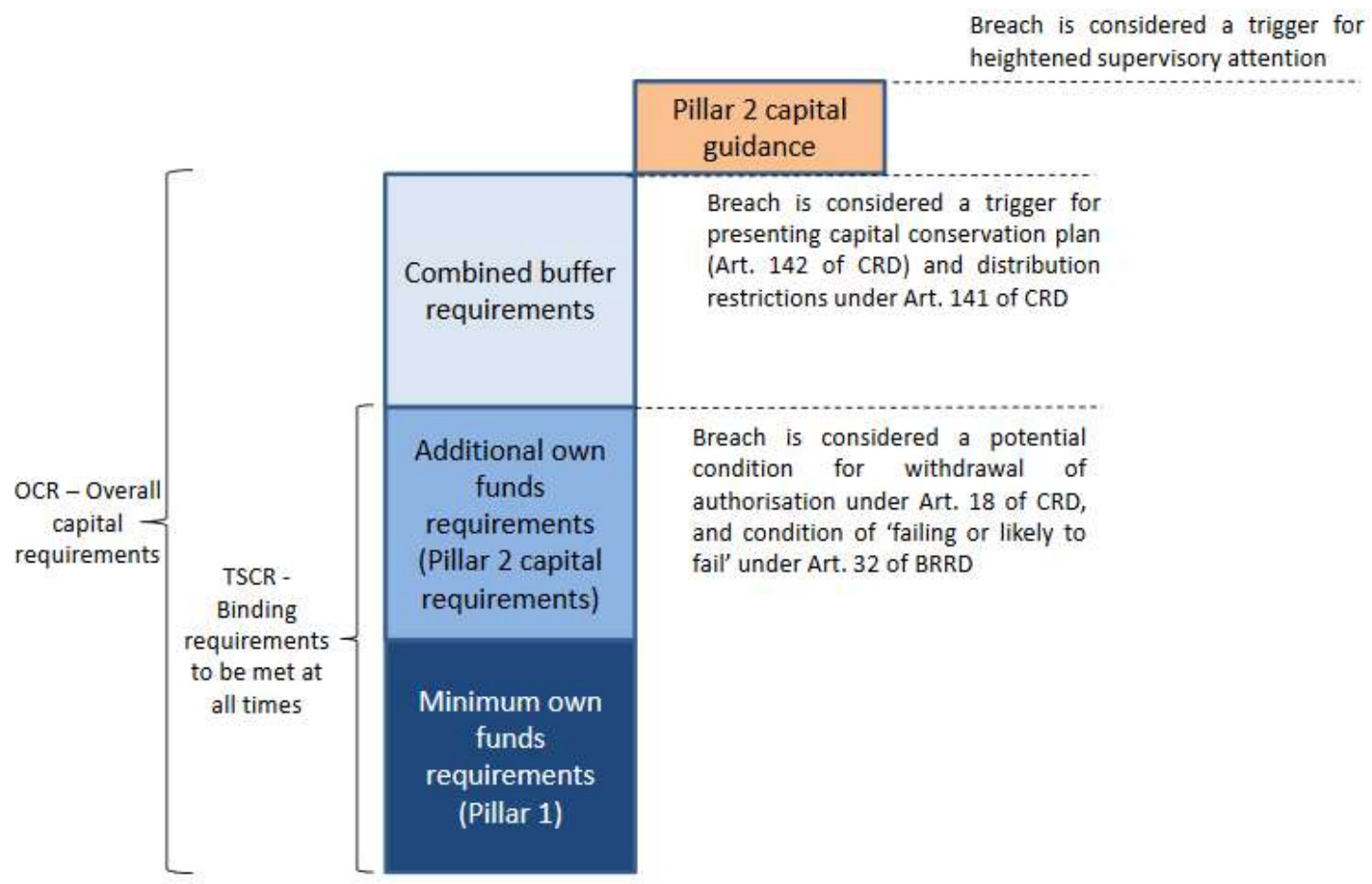

Source: EBA Pillar 2 Roadmap, p.4

Figure 1: Stacking order of capital requirements, and sanctions for breaching

\footnotetext{
${ }^{3}$ See https://eba.europa.eu/single-rule-book-qa/-/qna/view/publicId/2015_1759

${ }^{4}$ Article 141 of CRD IV

${ }^{5}$ Article 142 of CRD IV
} 
The CCyB framework was meant to enter into force on January 1st, 2016. Neverthe-

less, Sweden and Norway opted for early implementation and started using the CCyB as early as 2013.

\section{Empirical approach}

Our empirical approach consists in studying the impact of $\mathrm{CCyB}$ shocks on bank-level CDS spreads and stock prices. We follow standard methods for event studies (see for instance MacKinlay (1997)). We study events occurring during defined event windows - in our baseline the $(0,2)$ window - whereby the event takes place on the day of the announcement and in the two following days. In case investors take time to factor in new information, or if announcements are made at the end of business days, this allows us to fully capture the reaction of markets. Our result remain valid in alternative event specifications.

We specify our residuals covariance matrix as in Driscoll \& Kraay (1998) so that our estimates are robust to heteroskedasticity and serial cross-correlation of errors, a common feature in financial markets.

We define $\mathrm{CCyB}$ shocks as changes in $\mathrm{CCyB}$ level. Ideally, one would define shocks as unexpected $\mathrm{CCyB}$ changes, in which case the announcement of a constant $\mathrm{CCyB}$ could also come as a surprise. However, there are no financial instruments at our disposal to run such a study - as for instance Fed Funds Rate futures in monetary policy. Although in law the buffer guide could be a measure of market expectations, in practice CCyB rates implemented substantially differ from it due to the use of guided discretion. In Section D, we verify that markets do not react to announcements of constant $\mathrm{CCyB}$ rates. Conversely, the systematic reaction of markets upon announcements of $\mathrm{CCyB}$ changes validates the assumption that these come as (at least partial) surprises.

Our main regression consists in studying the effect of $\mathrm{CCyB}$ shocks on bank CDS spreads. As in Morgan et al. (2014), we control for variations in the iTraxx Europe Senior Financial 5-year, the CDS index for investment grade financial entities in Europe, produced by Markit. This index references senior debt of 30 European investment grade financial entities. We add a control for domestic currency value relative to the euro, given that several EEA countries operate in their own domestic currencies. Our main regression for bank $b$ resident of country $c$ at time $t$ writes:

$$
\begin{aligned}
\Delta C D S_{b c t}= & \beta * \Delta C C Y B_{b t}+\gamma_{1 b} * \Delta \operatorname{Itrax}_{t}+ \\
& \gamma_{2 b} * \Delta F O R E X_{c t}+F E_{b}+\epsilon_{b t}
\end{aligned}
$$

where $F E_{b}$ stands for the bank-specific fixed effects.

Our next important regression consists in studying the effect of $\mathrm{CCyB}$ shocks on bank 
stock returns. We opt for a market model of normal returns as in MacKinlay (1997), where bank-level stock returns are expressed as a linear function of their domestic stock return. We also add an exchange rate control. The regression for bank $b$ resident of country $c$ at time $t$ writes:

$$
\begin{aligned}
\text { StockReturn }_{b c t}= & \beta * \Delta C C Y B_{b t}+\gamma_{1 b} * \Delta \text { StockIndex }_{c t}+ \\
& \gamma_{2 b} * \Delta F O R E X_{c t}+F E_{b}+\epsilon_{b t}
\end{aligned}
$$

\section{Data}

The first task is to build bank-level CCyB shocks. For this, we proceed in three steps.

First, we collect all quarterly $\mathrm{CCyB}$ decisions by national authorities gathered by the European Systemic Risk Board up to November $2019^{6}$. We add to this list the decisions taken by the Hong-Kong authority. In the period of study (between 2013 and mid-2019), there were exactly $42 \mathrm{CCyB}$ changes in 15 countries (Figure 2). All changes but one were increases - the exception being the drop in $\mathrm{CCyB}$ announced in the UK on July 5th, 2016 following the Brexit vote. We exclude this change from baseline regressions due to the asymmetric nature of $\mathrm{CCyB}$ changes. Increases and releases differ in implementation delays and economic environment (economic expansion versus financial stress), and CCyB decreases may further be bundled in larger rescue packages. We study the Brexit release separately in a robustness exercise.

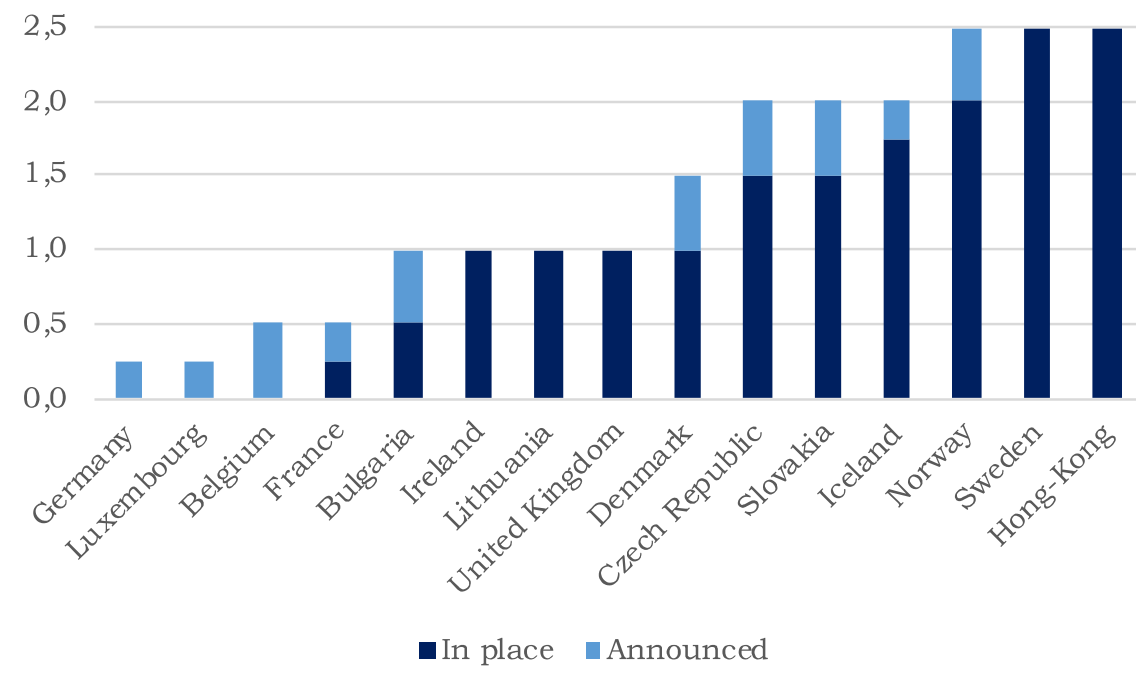

Figure 2: CCyB announced and in place in level as of November 2019 (in \% of RWA)

Second, we collect the exact date of CCyB announcements on national authorities'

\footnotetext{
${ }^{6}$ https://www.esrb.europa.eu/national_policy/ccb/html/index.en.html
} 
websites, taking into account potential differences in national frameworks. We choose the relevant announcement day to be the day of the first announcement of the increase, may it be a recommendation by the macroprudential authority, or a decision by the designated authority. When national authorities use forward guidance, we exclude both the initial guidance and the subsequent official announcement. Details on the identification of announcement dates are presented in Appendix A. We end up with 37 shocks in 15 countries, of magnitude between 0.25 and $1 \%$.

Third, we calculate bank-specific shocks which depend on bank geographic exposures. For that purpose, we limit ourselves to publicly-available information that investors could be using. We rely on country-level bank exposures coming from the EBA annual transparency exercise. Those exercises provide "detailed bank-by-bank data on capital positions, risk exposure amounts, leverage exposures and asset quality" for the largest banks of the European Economic Area (EEA) at the highest level of consolidation ${ }^{7}$.

The EBA dataset informs on geographical exposures and allows disentangling relevant credit risk exposures from non relevant credit risk exposures. In doing so, we use the share of relevant credit risk exposures as an approximation for the share of relevant exposures. We disregard the country-allocation of trading book and securitization exposures, as well as the difference between risk weighted exposures and their corresponding capital requirements. Both assumptions are credible to approximate investors behavior, as there is no other consistent public dataset on bank geographic exposures. In addition, credit risk exposures represent a large majority of total risk-weighted exposures. Using confidential information on French banks, we confirm that this approximation is very close to the true weights of national $\mathrm{CCyB}$ at the bank level. Therefore, informed market participants are able to measure quite precisely the real impact of the shock using the EBA data set.

We take into account the lag in the release of public information by the EBA. Precisely, the EBA publishes in December of year $n$ data for the second semester of year $n-1$ and the first semester of year $n$. We assume that investors estimate CCyB shocks of year $n+1$ using data published by the EBA in December of year $n$ on bank exposures at the end of the first semester of year $n$. Since the results of the first transparency exercise were published in December 2015, we restrict our analysis to CCyB increases starting in 2016. This also coincides with the entry into force of CRD IV. We are left with 31 shocks in 15 countries. In a robustness exercise, we retropolate bank exposures as of the first semester of 2015 to include the earliest shocks, which does not alter our results. Banks $\mathrm{CCyB}$ shocks are thus computed on day $t$ as

$$
\Delta C C y B_{b, t}=\sum_{c=1}^{N}\left\{\Delta C C y B_{c, t} * \frac{R W A_{b, c, t}^{\text {relevant, credit risk }}}{\sum_{k=1}^{N} R W A_{b, k, t}^{\text {relevant }, \text { credit risk }}}\right\}
$$

We match these shocks with bank-level market data on stock prices (from Bloomberg)

\footnotetext{
${ }^{7}$ https://eba.europa.eu/risk-analysis-and-data/eu-wide-transparency-exercise
} 
and 5-year CDS spreads (from Eikon, Markit, Bloomberg and Datastream). After excluding banks that underwent nationalization or bankruptcy over the period, we end up with a daily panel of stock returns for 58 European banks. Among these banks, we select those for which sufficiently liquid CDS spreads are available, using a liquidity score computed by Markit. Our final sample contains CDS spreads for 27 banks. Figure 3 presents the capital structures of the 58 banks in our sample, i.e. their capital requirement and the excess capital they hold on top, as of Q2 2019.

Finally, our baseline CDS analysis includes 171 bank-level shocks associated to 27 country-level increases, while our stock return analysis rests on 275 bank-level shocks associated to 28 country-level decisions. A detailed summary table is proposed in Appendix B. Key balance sheet and market statistics of the banks in the sample our referenced in Appendix C.

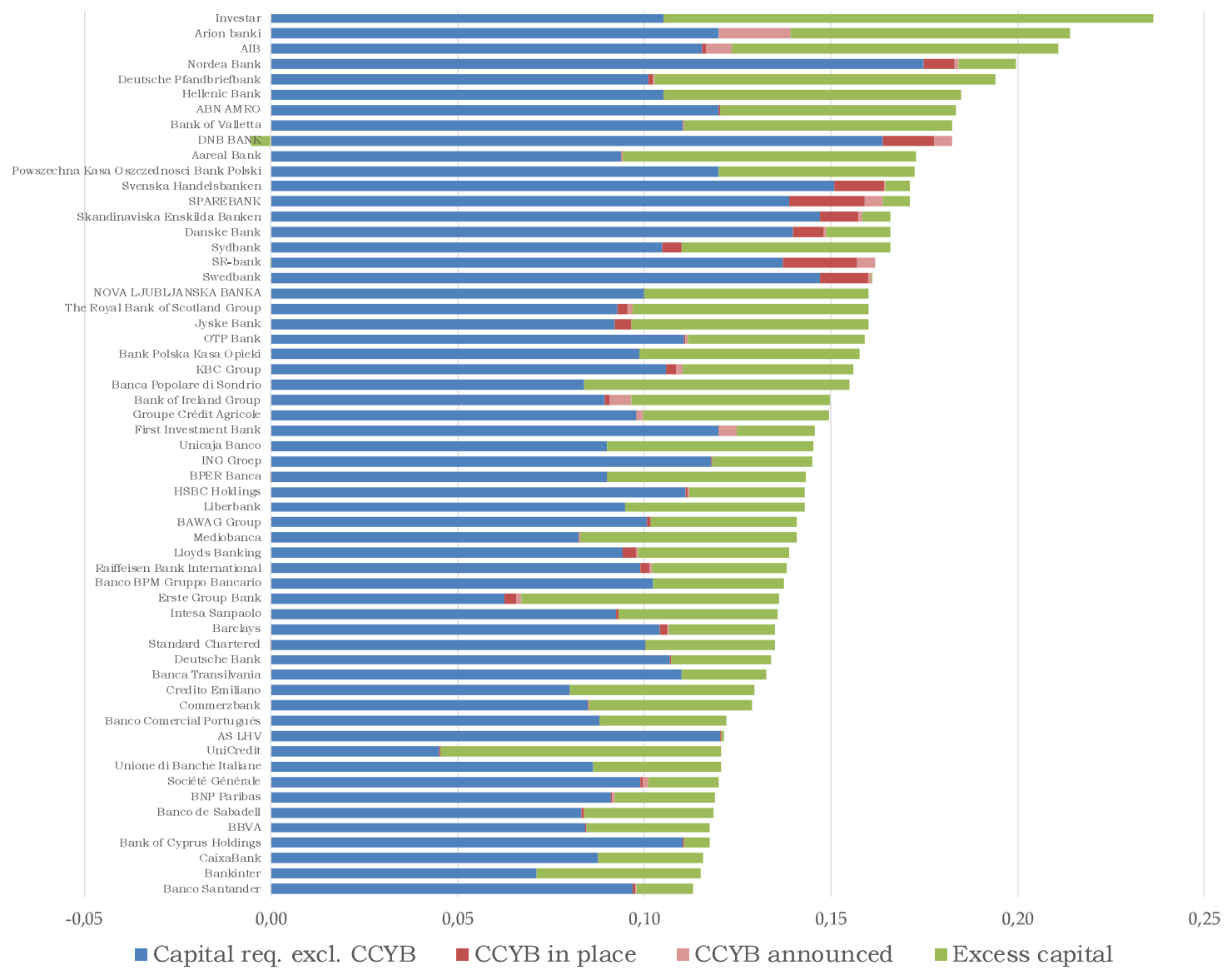

Note: CET1 capital, as a percentage of RWA. Capital requirements excluding CCyB include Pillar 1 requirements, the non-CCyB components of the Combined Buffer Requirements and the Pillar 2 requirements.

Figure 3: Capital structure of the 58 banks in the sample as of Q2 2019 (\% of RWA) 


\section{Results}

\subsection{CCyB impact on country-level market variables}

To begin with, we assess the impact of $\mathrm{CCyB}$ increases in a jurisdiction on country-level market variables. If $\mathrm{CCyB}$ increases convey private information on the state of a country's economy, we would expect those country-level variables to react on announcement days. We estimate the following regressions, where $\triangle C C Y B_{c t}$ takes the value of the CCyB increase in country $c$ :

$$
\Delta Y_{c t}=\beta * \Delta C C Y B_{c t}+\gamma_{c} * \Delta X_{c t}+F E_{c}+\epsilon_{c t}
$$

$\Delta Y_{c t}$ designates alternatively the daily variation in 5-year sovereign CDS spread, and the daily return of the main domestic stock index. We control respectively with the variation in the mean 5-year sovereign CDS spreads of countries in the sample, and with the return on European stock markets index produced by MSCI. We also examine the effect of announcements, replacing $\triangle C C Y B$ by a dummy taking value 1 whenever the latter is strictly positive.

Our estimates of $\beta$ are gathered in Table 1, and show that country-level variables do not react to $\mathrm{CCyB}$ announcements. This allows us to rule out the possibility that $\mathrm{CCyB}$ announcements systematically convey private information on the state of a country's financial cycle. Our results are robust to alternative specifications studied in Appendix D (Table 7).

\begin{tabular}{|c|c|c|c|c|}
\hline & \multicolumn{4}{|c|}{ Dependent variable: } \\
\hline & \multicolumn{2}{|c|}{ Stock return } & \multicolumn{2}{|c|}{$\Delta$ CDS sov } \\
\hline & $(1)$ & $(2)$ & $(3)$ & $(4)$ \\
\hline$\Delta \mathrm{CCYB}$ & $\begin{array}{c}0.00004 \\
(0.002)\end{array}$ & & $\begin{array}{c}0.061 \\
(0.056)\end{array}$ & \\
\hline Dummy & & $\begin{array}{c}-0.0004 \\
(0.001) \\
\end{array}$ & & $\begin{array}{c}0.036 \\
(0.030) \\
\end{array}$ \\
\hline Observations & 52,047 & 52,047 & 48,130 & 48,130 \\
\hline No. country shocks & 33 & 33 & 33 & 33 \\
\hline $\mathrm{R}^{2}$ & 0.001 & 0.001 & 0.190 & 0.190 \\
\hline Adjusted $\mathrm{R}^{2}$ & -0.0003 & -0.0003 & 0.188 & 0.188 \\
\hline
\end{tabular}

Note: All country-level CCyB increases since 2013 are included in the sample, excluding the 4 increases in Hong-Kong. All estimations are on a $(0,2)$ event window. Robust standard errors are shown in brackets. ${ }^{*} \mathrm{p}<0.1 ;{ }^{* *} \mathrm{p}<0.05 ;{ }^{* * *} \mathrm{p}<0.01$.

Table 1: Impact of $C C y B$ increases on domestic market variables 


\subsection{CCyB impact on bank CDS spreads}

We now turn to the main part of the paper and investigate the impact of CCyB hikes on banks CDS spreads.

To get a graphical idea of this effect, we plot abnormal changes in CDS spreads around announcements of $\mathrm{CCyB}$ hikes. First, we estimate a model of normal change in CDS spreads: we estimate Equation (3), removing the shock variable and excluding all dates in the $(-1,3)$ window. Using estimated coefficients, we compute abnormal changes in CDS spreads in those announcement windows. ${ }^{8}$. Finally, Figure 4 depicts the average cumulated abnormal change in bank CDS spreads around CCyB announcements, separating for each shock affected from unaffected banks. While CDS spreads of unaffected banks do not react, those of affected banks fall around announcements.

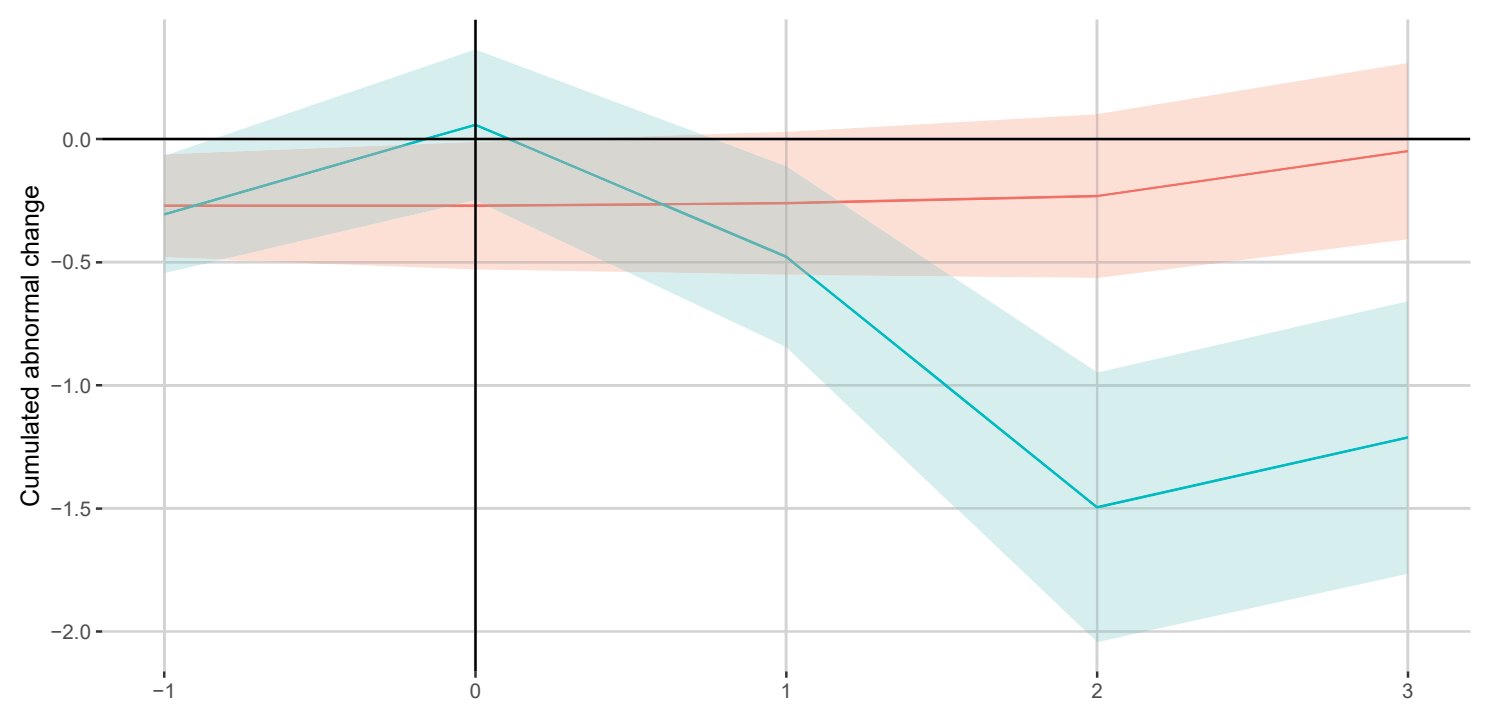

Note: Green (red) line indicates the cumulated abnormal change in CDS spread for (un)affected banks, in basis points. (Un)affected banks are banks receiving a strictly positive (null) CCyB shock on announcement days. Shaded areas correspond to $+/-1$ daily standard error. CCyB announcements with overlapping event windows are excluded.

Figure 4: Mean cumulated abnormal changes in CDS spreads around CCyB hikes

We confirm this result econometrically by estimating Equation (3). Results are shown in Table 2 and indicate that CCyB increases lead to lower CDS spreads for affected banks. These estimates are economically meaningful: a 1 percentage point increase in bank-level capital requirements leads to a drop of bank CDS spreads of 13 basis points (4.3 basis points spread over 3 days). In percentage of initial CDS spreads, this amounts to an $18 \%$ drop (Table 8). We also look at the effect of announcements by regressing CDS spread variations on dummies taking value 1 whenever there is a positive bank-specific shock

\footnotetext{
${ }^{8}$ This amounts to running the first-step of a two-step event study (see MacKinlay (1997))
} 
(resp. when there is a bank-specific shock of value in the fourth quartile). Announcements also predict drops in bank CDS spreads.

The negative impact of $\mathrm{CCyB}$ hikes on bank CDS spreads is the key result of this paper. It indicates that market participants consider that higher $\mathrm{CCyB}$ rates will lower bank probability of default. As such, the $\mathrm{CCyB}$ is expected to fulfill its main objective of increasing banks solvency.

These results are robust to a number of alternative specifications gathered in Appendix D. In particular, we verify that our results are robust to alternative specifications of normal CDS spread variations (Table 9). The result remains significant and of similar magnitude in all cases, except when we examine how affected CDS spreads react compared to the mean CDS spread of banks in our sample. In that case, the p-value falls slightly above $10 \%$, indicating that the mean CDS spread absorbs too much of the effect of our shocks. Our results are also persistent, with significant effects up to 5 days ahead (Table 10). They remain robust to using different liquidity criteria for selecting valid CDS (Table 11) and to removing country-level $\mathrm{CCyB}$ hikes one by one (Table 12).

Next, we include in our sample 6 other events that occurred before 2016, when bank country exposures were not publicly available. We retropolate bank country exposures from the last available observation assuming exposures were stable. Implicitly, we assume investors were able to estimate bank country exposures through other publications. Our results are also robust to this specification (Table 13).

Finally, we run a placebo test, randomly assigning CCyB shocks in the dataset. Table 14 reports no spurious significant effect of those placebo shocks.

\begin{tabular}{lcccc}
\hline \hline & \multicolumn{4}{c}{ Dependent variable: $\Delta$ CDS } \\
\cline { 2 - 5 } & Baseline & Large shocks & Baseline & Large shocks \\
& $(1)$ & $(2)$ & $(3)$ & $(4)$ \\
\hline$\Delta$ CCYB & $-4.253^{* * *}$ & $-3.951^{* *}$ & & \\
& $(1.564)$ & $(1.676)$ & & $-0.527^{*}$ \\
Dummy & & & $-0.366^{*}$ & $(0.191)$ \\
& & & 25,294 & 25,159 \\
\hline Observations & 25,294 & 25,159 & 27 & 14 \\
No. country shocks & 27 & 14 & 171 & 36 \\
No. bank shocks & 171 & 36 & 0.179 & 0.179 \\
$\mathrm{R}^{2}$ & 0.179 & 0.179 & 0.177 & 0.177 \\
Adjusted R & & & &
\end{tabular}

Notes: Dummy takes value 1 whenever there is a positive CCyB shock (Baseline) or a CCyB shock in the fourth quartile of magnitude (Large shocks). All estimations are on a $(0,2)$ event window. Robust standard errors are shown in brackets. ${ }^{*} \mathrm{p}<0.1 ;{ }^{* *} \mathrm{p}<0.05 ;{ }^{* * *} \mathrm{p}<0.01$.

Table 2: Impact of $C C y B$ increases on bank $C D S$ spreads 
To better understand the drivers of the result, we run a range of complementary estimations summarized in Table 3.

First, we investigate whether domestic shocks matter more than foreign shocks for a bank. It turns out results are largely driven by domestic shocks. This could reflect informational frictions, in the sense that investors could be not fully aware of the bank's country exposures and its corresponding exposure to $\mathrm{CCyB}$ increases. Another explanation is that foreign shocks are smaller in magnitude since banks display a domestic bias in credit risk exposures. This may reduce the power of testing for the impact of foreign shocks.

We also find that $\mathrm{CCyB}$ activation (i.e. its first increase in a given country) has a slightly larger effect. Upon activation, authorities likely enhance their communication, while some investors may learn about the instrument for the first time. First announcements may be less anticipated than other ones, and the impact estimate therefore be less conservative.

We study separately the single $\mathrm{CCyB}$ release in our sample, taking place in the UK in July 5th, 2016 following the Brexit vote. This 1 percentage point CCyB drop affects 22 banks across the EEA in our sample. The effect is negative, which means that CDS spreads abnormally increased on that day.

\begin{tabular}{lccccc}
\hline \hline & \multicolumn{5}{c}{ Dependent variable: $\Delta C D S$} \\
\cline { 2 - 6 } & Baseline & Domestic & Foreign & First & Brexit \\
& $(1)$ & $(2)$ & $(3)$ & $(4)$ & $(5)$ \\
\hline$\Delta$ CCYB & $-4.253^{* * *}$ & $-4.735^{* * *}$ & -1.750 & $-5.794^{* * *}$ & $-3.740^{*}$ \\
& $(1.564)$ & $(1.722)$ & $(3.462)$ & $(2.123)$ & $(2.082)$ \\
\hline Observations & 25,294 & 25,294 & 25,272 & 25,228 & 24,855 \\
No. country shocks & 27 & 8 & 27 & 11 & 1 \\
No. bank shocks & 171 & 22 & 149 & 105 & 22 \\
$\mathrm{R}^{2}$ & 0.179 & 0.179 & 0.179 & 0.179 & 0.180 \\
Adjusted R ${ }^{2}$ & 0.177 & 0.177 & 0.177 & 0.177 & 0.178 \\
\hline \hline
\end{tabular}

Notes: Domestic restricts the analysis to bank shocks due to shocks decided in the bank's country of residence. Conversely, Foreign restricts the analysis to shocks decided outside the bank's country of residence. First focuses on CCyB activations, as opposed to increases. Brexit looks at the impact of the Brexit $\mathrm{CCyB}$ release of 2016. Robust standard errors are shown in brackets. ${ }^{*} \mathrm{p}<0.1 ;{ }^{* *} \mathrm{p}<0.05$; ${ }^{* * *} \mathrm{p}<0.01$.

Table 3: Impact of $C C y B$ increases on bank CDS spreads - Specific investigations

\subsection{CCyB impact on stock prices}

In this section, we estimate Equation 4 and assess whether CDS spread drops are associated with changes in stock returns. Results are summarized in Table 4. It appears that $\mathrm{CCyB}$ increases are not associated with any systematic stock price movement. These 
results are robust to using a $(0,1)$ event-window, as highlighted in Table 15.

There are three reasons why capital requirements could leave stock returns unaffected.

First, pecking-order (Myers \& Majluf (1984)) and market timing (Baker \& Wurgler (2002)) theories predict that capital structure matters only in the presence of information frictions. In those theories, equity issuance due to higher capital requirements do not affect stock prices since they do not convey any private information. As in Cornett \& Tehranian (1994), we indeed find that regulatory-driven capital structure adjustments do not affect stock prices since they do not convey any bank manager private information.

On the other hand, we cannot reject altogether trade-off theories. These theories point to the existence of an optimal leverage ratio (Kraus \& Litzenberger (1973)). In such framework, any higher capital requirement would automatically force a firm to deviate from its optimal leverage, and entail lower stock prices. However, if shareholders target an optimal range of leverage instead of a specific ratio, any $\mathrm{CCyB}$ increase allowing banks to remain in that range may come at no cost for shareholders. This may be the case since regulators generally increase the $\mathrm{CCyB}$ in small steps and give banks one year to adjust precisely to avoid abrupt deleveraging.

Finally, as CCyB hikes are relatively modest, banks may be able to adjust with retained earnings and at least avoid transaction costs attached to equity issuance.

Disentangling those different effects is beyond the scope of this paper. What we show is that observed $\mathrm{CCyB}$ increases did not trigger any stock price decline. This suggests that regulators may have further room to tighten capital requirements at no cost for shareholders.

\begin{tabular}{|c|c|c|c|c|c|c|}
\hline & \multicolumn{6}{|c|}{ Dependent variable: Stock return } \\
\hline & $\begin{array}{c}\text { Baseline } \\
(1)\end{array}$ & $\begin{array}{c}\text { Large shock } \\
(2)\end{array}$ & $\begin{array}{c}\text { Baseline } \\
(3)\end{array}$ & $\begin{array}{c}\text { Large shock } \\
(4)\end{array}$ & $\begin{array}{c}\text { CDS sample } \\
(5)\end{array}$ & $\begin{array}{c}\text { CDS sample } \\
(6) \\
\end{array}$ \\
\hline$\Delta \mathrm{CCYB}$ & $\begin{array}{c}0.004 \\
(0.006)\end{array}$ & $\begin{array}{c}0.004 \\
(0.005)\end{array}$ & & & $\begin{array}{c}0.005 \\
(0.012)\end{array}$ & \\
\hline Dummy & & & $\begin{array}{c}0.0003 \\
(0.002) \\
\end{array}$ & $\begin{array}{c}0.002 \\
(0.002)\end{array}$ & & $\begin{array}{c}0.0002 \\
(0.002) \\
\end{array}$ \\
\hline Observations & 51,589 & 51,373 & 51,589 & 51,373 & 25,294 & 25,294 \\
\hline No. country shocks & 28 & 19 & 28 & 19 & 27 & 27 \\
\hline No. bank shocks & 275 & 59 & 275 & 59 & 171 & 171 \\
\hline $\mathrm{R}^{2}$ & 0.436 & 0.437 & 0.436 & 0.437 & 0.536 & 0.536 \\
\hline Adjusted $\mathrm{R}^{2}$ & 0.435 & 0.435 & 0.435 & 0.435 & 0.535 & 0.535 \\
\hline
\end{tabular}

Note: Dummy takes value 1 whenever there is a positive CCYB shock (Baseline) or a CCYB shock in the fourth quartile of magnitude (Large shocks). The CDS sample regressions estimate the stock return equation on points of the panel when CDS spreads are defined to allow for comparisons. Robust standard errors are shown in brackets. ${ }^{*} \mathrm{p}<0.1 ;{ }^{* *} \mathrm{p}<0.05 ;{ }^{* * *} \mathrm{p}<0.01$

Table 4: Impact of CCyB increases on bank stock returns 


\section{Conclusion}

In this paper, we exploit the novel institutional setup of the CCyB in the EEA to directly estimate the effect of capital requirements on financial markets. Our identification rests upon two features: $\mathrm{CCyB}$ hikes are quarterly announcements by national authorities, and they heterogeneously affect all banks of the EEA. We use this setup to assess how markets factor capital requirement increases in CDS spreads and stock prices.

We show that hikes in $\mathrm{CCyB}$ rates are perceived as increasing bank solvency, at no significant cost for shareholders. We claim that these effects relate to the capital constraint itself, as opposed to the potential signal conveyed on the state of the financial cycle. These results are important to assess the costs and benefits of capital requirements. They suggest that regulators may have further room to tighten capital requirements without triggering negative stock returns.

Our results pave the way for further research, as the use of the CCyB becomes more widespread. As we write, the COVID-19 pandemic has also triggered a range of CCyB

releases. Key questions relate to the impact of the $\mathrm{CCyB}$ on credit growth, and to the asymmetric impact of hikes and releases of capital requirements 


\section{References}

Annaert, J., De Ceuster, M., Van Roy, P. \& Vespro, C. (2013), 'What determines euro area bank cds spreads?', Journal of International Money and Finance 32, $444-461$.

Auer, R. \& Ongena, S. (2016), 'The countercyclical capital buffer and the composition of bank lending', BIS Working Papers 593.

Baker, M. \& Wurgler, J. (2002), 'Market timing and capital structure', The Journal of Finance 57(1), 1-32.

Benbouzid, N., Mallick, S. K. \& Sousa, R. M. (2017), 'An international forensic perspective of the determinants of bank cds spreads', Journal of Financial Stability 33, 60 70 .

Carboni, M., Fiordelisi, F., Ricci, O. \& Lopes, F. S. S. (2017), 'Surprised or not surprised? the investors' reaction to the comprehensive assessment preceding the launch of the banking union', Journal of Banking $\&$ Finance 74, 122 - 132.

Clerc, L., Derviz, A., Mendicino, C., Moyen, S., Nikolov, K., Stracca, L., Suarez, J. \& Vardoulakis, A. P. (2015), 'Capital Regulation in a Macroeconomic Model with Three Layers of Default', International Journal of Central Banking 11(3), 9-63.

Cornett, M. M. \& Tehranian, H. (1994), 'An examination of voluntary versus involuntary security issuances by commercial banks: The impact of capital regulations on common stock returns', Journal of Financial Economics 35(1), 99 - 122.

Driscoll, J. C. \& Kraay, A. C. (1998), 'Consistent covariance matrix estimation with spatially dependent panel data', The Review of Economics and Statistics 80(4), 549560.

Elyasiani, E., J., L. \& Pagano, M. S. (2014), 'Large capital infusions, investor reactions, and the return and risk-performance of financial institutions over the business cycle', Journal of Financial Stability 11, $62-81$.

ESRB (2014), 'Recommendation of the european systemic risk board of 18 june 2014 on guidance for setting countercyclical buffer rates (esrb/2014/1)', Official Journal of the European Union.

Fraisse, H., Le, M. \& Thesmar, D. (2019), 'The real effects of bank capital requirements', Management Science 66(1).

Jimenez, G., Ongena, S., Peydro, J.-L. \& Saurina, J. (2017), 'Macroprudential policy, countercyclical bank capital buffers, and credit supply: Evidence from the spanish dynamic provisioning experiments', Journal of Political Economy 125(6). 
Kraus, A. \& Litzenberger, R. H. (1973), 'A state-preference model of optimal financial leverage', The Journal of Finance 28(4), 911-922.

MacKinlay, C. (1997), 'Event studies in economics and finance', Journal of Economic Literature 35, 13-39.

Morgan, D. P., Peristiani, S. \& Savino, V. (2014), 'The information value of the stress test', Journal of Money, Credit and Banking 46(7), 1479-1500.

Myers, S. C. \& Majluf, N. S. (1984), 'Corporate financing and investment decisions when firms have information that investors do not have', Journal of Financial Economics 13(2), $187-221$.

Mésonnier, J.-S. \& Monks, A. (2015), 'Did the EBA Capital Exercise Cause a Credit Crunch in the Euro Area?', International Journal of Central Banking 11(3), 75-117.

Petrella, G. \& Resti, A. (2013), 'Supervisors as information producers: Do stress tests reduce bank opaqueness?', Journal of Banking \& Finance 37(12), 5406-5420.

Repullo, R. \& Suarez, J. (2012), 'The Procyclical Effects of Bank Capital Regulation', The Review of Financial Studies 26(2), 452-490. 


\section{Appendices}

\section{A Identification of $\mathrm{CCyB}$ announcement dates}

To identify announcement days, we watch out for two pitfalls. First, there may be distinct macroprudential and designated authorities, with the former making CCyB recommendations and the latter taking $\mathrm{CCyB}$ decisions. Second, authorities may be providing guidance on the path of future CCyB rates.

European law mandates the establishment of both a macroprudential authority in charge of conducting macroprudential policy ${ }^{9}$, and a designated authority in charge of deciding $\mathrm{CCyB}$ rates $^{10}$. In some countries the same institution plays both roles, while in some not ${ }^{11}$. Among countries that activated, Denmark, Luxembourg, Germany, and Iceland have a distinct macroprudential authority publishing recommendations 1 to 3 month prior to the designated authority decision. In all cases, macroprudential authority recommendations have been followed up by a decision. We consider the relevant announcement day to be the first public announcement of the $\mathrm{CCyB}$ change, may it be a macroprudential authority recommendation or a designated authority decision.

When authorities provide guidance on the path of future CCyB rates, we exclude

the initial guidance as well as the subsequent official announcement. Forward guidance announcements would not be directly comparable to official announcements, since they become effective more than a year after they are made. Subsequent announcements should be largely anticipated. In Denmark, the macroprudential authority (the Systemic Risk Council) can provide forward guidance on future recommendations in the same press release as that of the current recommendation (it occurred on April 4, 2018, March 26, 2018 and September 25, 2018). Swedish and British designated authorities also used forward guidance (resp. on July 13, 2018 and June 27, 2017).

\footnotetext{
${ }^{9}$ See Recommendation ESRB/2011/3 of the European Systemic Risk Board on the macro-prudential mandate of national authorities: https://www.esrb.europa.eu/pub/pdf/recommendations/ESRB_ 2011_3.en.pdf

${ }^{10}$ See Article $136(1)$ of CRD IV.

${ }^{11} \mathrm{~A}$ full list of countries depending on their institutional arrangement is available here: https://www.esrb.europa.eu/national_policy/shared/pdf/esrb.191125_list_national\%20_ macroprudential_authorities_and_national_designated_authorities_in_EEA_Member_States. en.pdf
} 


\section{B Summary statistics on CCyB shocks}

\begin{tabular}{|c|c|c|c|c|c|c|c|c|c|c|}
\hline Date & Country CCYB & CCYB & ALL & CDS & Large & Min & Median & Mean & $\operatorname{Pctl}(75)$ & Max \\
\hline 2016-01-14 & Hong Kong & 0.62 & 3 & 3 & 2 & 0.00 & 0.07 & 0.05 & 0.07 & 0.07 \\
\hline $2016-03-15$ & Sweden & 0.50 & 9 & 5 & 3 & 0.03 & 0.10 & 0.13 & 0.20 & 0.24 \\
\hline 2016-03-29 & United Kingdom & 0.50 & 35 & 22 & 6 & 0.00 & 0.01 & 0.06 & 0.06 & 0.41 \\
\hline $2016-07-26$ & Slovakia & 0.50 & 5 & 3 & 0 & 0.01 & 0.03 & 0.03 & 0.04 & 0.05 \\
\hline $2016-12-15$ & Norway & 0.50 & 7 & 5 & 2 & 0.04 & 0.06 & 0.11 & 0.08 & 0.32 \\
\hline $2017-01-27$ & Hong Kong & 0.62 & 3 & 3 & 2 & 0.00 & 0.07 & 0.05 & 0.07 & 0.07 \\
\hline $2017-06-13$ & Czech Republic & 0.50 & 5 & 4 & 1 & 0.01 & 0.04 & 0.04 & 0.06 & 0.09 \\
\hline $2017-06-27$ & United Kingdom & 0.50 & 36 & 23 & 7 & 0.00 & 0.02 & 0.06 & 0.07 & 0.40 \\
\hline $2017-07-10$ & Slovakia & 0.75 & 5 & 3 & 1 & 0.02 & 0.05 & 0.05 & 0.06 & 0.07 \\
\hline $2017-12-18$ & Czech Republic & 0.25 & 5 & 4 & 0 & 0.01 & 0.02 & 0.02 & 0.03 & 0.05 \\
\hline $2017-12-20$ & Denmark & 0.50 & 7 & 5 & 2 & 0.00 & 0.04 & 0.08 & 0.13 & 0.21 \\
\hline $2017-12-21$ & Lithuania & 0.50 & 4 & 2 & 0 & 0.01 & 0.02 & 0.02 & 0.03 & 0.03 \\
\hline 2018-01-10 & Hong Kong & 0.62 & 3 & 3 & 2 & 0.00 & 0.07 & 0.06 & 0.09 & 0.10 \\
\hline 2018-06-11 & France & 0.25 & 27 & 15 & 2 & 0.00 & 0.00 & 0.03 & 0.01 & 0.17 \\
\hline 2018-06-12 & Czech Republic & 0.25 & 5 & 4 & 0 & 0.01 & 0.02 & 0.02 & 0.03 & 0.05 \\
\hline 2018-06-21 & Lithuania & 0.50 & 4 & 2 & 0 & 0.01 & 0.02 & 0.02 & 0.02 & 0.03 \\
\hline 2018-07-03 & Slovakia & 0.25 & 5 & 3 & 0 & 0.01 & 0.02 & 0.02 & 0.02 & 0.02 \\
\hline 2018-07-05 & Ireland & 1.00 & 8 & 3 & 1 & 0.01 & 0.03 & 0.05 & 0.06 & 0.10 \\
\hline 2018-09-26 & Bulgaria & 0.50 & 4 & 1 & 0 & 0.01 & 0.01 & 0.01 & 0.01 & 0.01 \\
\hline 2018-12-10 & Luxembourg & 0.25 & 11 & 9 & 0 & 0.00 & 0.00 & 0.00 & 0.00 & 0.01 \\
\hline 2018-12-13 & Norway & 0.50 & 8 & 5 & 3 & 0.04 & 0.07 & 0.11 & 0.09 & 0.30 \\
\hline 2018-12-14 & Czech Republic & 0.25 & 5 & 4 & 0 & 0.01 & 0.02 & 0.02 & 0.03 & 0.05 \\
\hline 2018-12-19 & Iceland & 0.25 & 1 & 0 & 0 & 0.00 & 0.00 & 0.00 & 0.00 & 0.00 \\
\hline 2019-03-18 & France & 0.25 & 27 & 14 & 2 & 0.00 & 0.01 & 0.03 & 0.01 & 0.17 \\
\hline 2019-03-29 & Bulgaria & 0.50 & 4 & 1 & 0 & 0.01 & 0.01 & 0.01 & 0.01 & 0.01 \\
\hline 2019-05-27 & Germany & 0.25 & 28 & 19 & 0 & 0.00 & 0.01 & 0.01 & 0.01 & 0.03 \\
\hline 2019-06-28 & Belgium & 0.50 & 6 & 3 & 0 & 0.01 & 0.05 & 0.04 & 0.05 & 0.06 \\
\hline \multirow[t]{2}{*}{ 2019-07-23 } & Slovakia & 0.50 & 5 & 3 & 0 & 0.01 & 0.04 & 0.03 & 0.04 & 0.04 \\
\hline & Total & & 275 & 171 & 36 & 0.00 & 0.01 & 0.04 & 0.05 & 0.41 \\
\hline
\end{tabular}

Notes: Statistics refer to positive CCyB shocks that were announced beginning in 2016. ALL refers to the total number of bank shocks in our stock price sample. $C D S$ refers to the total number of bank shocks in our CDS sample. Large refers to the total number of bank shocks of value in the fourth quartile. Further statistics on CCyB shocks are restricted $C D S$ bank shocks.

Table 5: Summary statistics of 28 country-level CCyB increases in the sample 


\section{Summary statistics on banks}

\begin{tabular}{lcccccccc}
\hline \hline Statistic & Unit & $\mathrm{N}$ & Mean & St. Dev. & Min & Pctl(25) & Pctl(75) & Max \\
\hline Stock return & pp & 25,360 & -0.02 & 2.0 & -25 & -1.0 & 0.9 & 16 \\
PD 5Y & pp & 25,360 & 2.4 & 1.0 & 1.5 & 1.9 & 2.6 & 14.3 \\
CDS & bp & 25,360 & 97.7 & 87.4 & 15.4 & 48.2 & 122.2 & 912.4 \\
$\Delta$ CDS & bp & 25,360 & -0.1 & 4.4 & -164.6 & -0.9 & 0.7 & 118.1 \\
CDS growth & pp & 25,360 & -0.002 & 0.05 & -2.9 & -0.01 & 0.01 & 0.7 \\
TA & EUR bn & 24,316 & 715.0 & 620.0 & 0.0 & 212.5 & 957.8 & $2,417.8$ \\
Total RWA & EUR bn & 24,617 & 247.0 & 212.3 & 27.2 & 71.9 & 360.2 & $1,013.1$ \\
RW & pp & 24,029 & 0.4 & 0.1 & 0.0 & 0.3 & 0.5 & 0.8 \\
CET1 ratio & pp & 25,360 & 14.0 & 2.7 & 8.2 & 12.0 & 14.8 & 25.1 \\
LR & pp & 18,397 & 5.5 & 1.1 & 3.6 & 4.7 & 6.0 & 9.5 \\
Excess capital & pp & 25,360 & 4.0 & 1.9 & -1.6 & 2.8 & 5.3 & 8.1 \\
\hline
\end{tabular}

Notes: There are 57 banks with defined stock returns in our sample, but we focus here on the 27 banks that have defined CDS spreads. Excess capital corresponds to the difference between observed capital ratios and capital requirements. In cases when capital requirements are not published, they are guessed using published capital requirements, and an average pillar 2 requirement of $2 \%$.

Table 6: Summary statistics of 27 banks with defined CDs spreads in the sample 


\section{Robustness tests}

\section{D.1 Robustness of country-level results}

\begin{tabular}{|c|c|c|c|c|c|}
\hline & \multicolumn{5}{|c|}{ Dependent variable: } \\
\hline & \multicolumn{2}{|c|}{ Stock index return } & \multicolumn{3}{|c|}{$\Delta$ CDS sov } \\
\hline & $\begin{array}{c}2016+ \\
(1)\end{array}$ & $\begin{array}{c}(0,1) \\
(2)\end{array}$ & $\begin{array}{c}2016+ \\
(3)\end{array}$ & $\begin{array}{c}(0,1) \\
(4)\end{array}$ & $\begin{array}{c}\text { Itraxx } \\
(5)\end{array}$ \\
\hline$\Delta \mathrm{CCYB}$ & $\begin{array}{c}-0.00001 \\
(0.002)\end{array}$ & $\begin{array}{c}0.0004 \\
(0.002)\end{array}$ & $\begin{array}{c}0.082 \\
(0.073)\end{array}$ & $\begin{array}{c}0.064 \\
(0.073)\end{array}$ & $\begin{array}{c}0.025 \\
(0.064)\end{array}$ \\
\hline Observations & 28,557 & 52,048 & 26,653 & 48,131 & 48,130 \\
\hline No. country shocks & 28 & 33 & 28 & 33 & 33 \\
\hline $\mathrm{R}^{2}$ & 0.010 & 0.001 & 0.185 & 0.190 & 0.004 \\
\hline Adjusted $\mathrm{R}^{2}$ & 0.008 & -0.0003 & 0.183 & 0.188 & 0.002 \\
\hline
\end{tabular}

$2016+$ excludes shocks that occurred prior to 2016. $(0,1)$ run regressions using the $(0,1)$ event window. Itraxx specifies sovereign CDS as a linear function of the iTraxx Europe Senior Financial 5-year CDS index. By default, estimations are on a $(0,2)$ event window. Robust standard errors are shown in brackets. ${ }^{*} \mathrm{p}<0.1 ;{ }^{* *} \mathrm{p}<0.05 ;{ }^{* * *} \mathrm{p}<0.01$.

Table 7: Robustness of country-level results

\section{D.2 Results using CDS growth rate as dependent variable}

\begin{tabular}{lcccc}
\hline \hline & \multicolumn{4}{c}{ Dependent variable: $d C D S$} \\
\cline { 2 - 5 } & Baseline & Large shocks & Baseline & Large shocks \\
& $(1)$ & $(2)$ & $(3)$ & $(4)$ \\
\hline \hline$\Delta$ CCYB & $-0.062^{* * *}$ & $-0.054^{* * *}$ & \\
& $(0.021)$ & $(0.020)$ & & \\
Dummy & & & -0.005 & $-0.009^{* *}$ \\
& \multicolumn{4}{c}{$0.003)$} \\
\hline Observations & 25,294 & 24,895 & 25,294 & 24,895 \\
No. country shocks & 27 & 14 & 27 & 14 \\
No. bank shocks & 171 & 36 & 171 & 36 \\
$\mathrm{R}^{2}$ & 0.179 & 0.178 & 0.179 & 0.178 \\
Adjusted $\mathrm{R}^{2}$ & 0.177 & 0.176 & 0.177 & 0.176 \\
\hline \hline
\end{tabular}

Notes: $d C D S$ is the bank level CDS spread growth rate, defined as $\frac{\triangle C D S}{C D S}$. Dummy takes value 1 whenever there is a positive $\mathrm{CCyB}$ shock (Baseline) or a $\mathrm{CCyB}$ shock of value in the fourth quartile (Large shocks). All estimations are on a $(0,2)$ event window. Robust standard errors are shown in brackets. ${ }^{*} \mathrm{p}<0.1 ;{ }^{* *} \mathrm{p}<0.05 ;{ }^{* * *} \mathrm{p}<0.01$.

Table 8: Impact of $C C y B$ increases on bank $C D S$ spread growth rate 


\section{D.3 Robustness to alternative specifications for normal CDS spread variation}

\begin{tabular}{lccccc}
\hline \hline & \multicolumn{5}{c}{ Dependent variable: $\Delta$ CDS } \\
\cline { 2 - 5 } & Baseline & Sovereign CDS & Mean CDS & Itraxx Europe & No control \\
& $(1)$ & $(2)$ & $(3)$ & $(4)$ & $(5)$ \\
\hline$\Delta$ CCYB & $-4.253^{* * *}$ & $-4.966^{* * *}$ & -1.970 & $-4.685^{* * *}$ & $-4.667^{* *}$ \\
& $(1.564)$ & $(1.820)$ & $(1.735)$ & $(1.749)$ & $(1.924)$ \\
\hline Obscrvations & 25,294 & 25,294 & 25,294 & 25,294 & 25,294 \\
No. country shocks & 27 & 27 & 27 & 27 & 27 \\
No. bank shocks & 171 & 171 & 171 & 171 & \\
$\mathrm{R}^{2}$ & 0.179 & 0.138 & 0.277 & 0.160 & 0.006 \\
Adjusted R $\mathrm{R}^{2}$ & 0.177 & 0.136 & 0.275 & 0.158 & 0.005 \\
\hline \hline
\end{tabular}

Notes: Sovereign CDS controls for sovereign CDS spread variation. Mean CDS controls for the variation of the mean of CDS spreads in our sample.Itraxx Europe controls for the European index of CDS spreads, which includes non financial firms and non-investment grade corporates. No control simply examines the variation of CDS spreads on announcement days without any control. ${ }^{*} \mathrm{p}<0.1 ;{ }^{* *} \mathrm{p}<0.05 ;{ }^{* * *} \mathrm{p}<0.01$.

Table 9: Robustness to alternative specifications for normal CDS spread variations

\section{D.4 Persistence}

\begin{tabular}{lcccc}
\hline \hline & \multicolumn{4}{c}{ Dependent variable: $\Delta C D S$} \\
\cline { 2 - 5 } & $(0,0)$ & $(0,1)$ & $(0,2)$ & $(0,5)$ \\
& $(1)$ & $(2)$ & $(3)$ & $(4)$ \\
\hline$\Delta$ CCYB & -1.049 & $-3.001^{*}$ & $-4.253^{* * *}$ & $-2.556^{* *}$ \\
& $(2.897)$ & $(1.754)$ & $(1.564)$ & $(1.156)$ \\
& $p=0.718$ & $p=0.088$ & $p=0.007$ & $p=0.028$ \\
\hline Observations & 25,338 & 25,316 & 25,294 & 25,228 \\
$\mathrm{R}^{2}$ & 0.179 & 0.179 & 0.179 & 0.179 \\
Adjusted $\mathrm{R}^{2}$ & 0.177 & 0.177 & 0.177 & 0.177 \\
\hline \hline
\end{tabular}

Notes: Event windows are defined with a tuple, with the first item referring to the first day of the event, and the second referring to the last day of the event. Days are counted relative to day 0 - the day of the announcement itself. ${ }^{*} \mathrm{p}<0.1 ;{ }^{* *} \mathrm{p}<0.05 ;{ }^{* *} \mathrm{p}<0.01$.

Table 10: Persistence of the impact of $C C y B$ increases on bank CDS spreads 


\section{D.5 Robustness to selection of banks based on their CDS liq- uidity}

\begin{tabular}{lccccc}
\hline \hline & \multicolumn{5}{c}{ Dependent variable: $\Delta$ CDS } \\
\cline { 2 - 6 } & All & Baseline (LS $<5)$ & LS $<4$ & LS $<3$ & LS $<2$ \\
& $(1)$ & $(2)$ & $(3)$ & $(4)$ & $(5)$ \\
\hline$\Delta$ CCYB & $-3.566^{* *}$ & $-4.253^{* * *}$ & $-4.044^{* *}$ & $-4.040^{* *}$ & $-4.300^{* *}$ \\
& $(1.462)$ & $(1.564)$ & $(1.591)$ & $(1.592)$ & $(1.811)$ \\
& $p=0.015$ & $p=0.007$ & $p=0.012$ & $p=0.012$ & $p=0.018$ \\
\hline Observations & 26,707 & 25,294 & 18,639 & 17,038 & 14,191 \\
No. country shocks & 27 & 27 & 25 & 25 & 25 \\
No. bank shocks & 179 & 171 & 133 & 130 & 107 \\
$\mathrm{R}^{2}$ & 0.178 & 0.179 & 0.188 & 0.208 & 0.208 \\
Adjusted R ${ }^{2}$ & 0.176 & 0.177 & 0.186 & 0.206 & 0.206 \\
\hline \hline
\end{tabular}

Notes: All uses all available CDS time series. Next regressions successively exclude CDS for which the liquidity score (LS) is above a certain score (5: least liquid; 1 : most liquid). ${ }^{*} \mathrm{p}<0.1 ;{ }^{* *} \mathrm{p}<0.05$; ${ }^{* * *} \mathrm{p}<0.01$.

Table 11: Robustness to using different samples of CDS depending on their liquidity 


\section{D.6 Robustness to removing country shocks individually}

\begin{tabular}{ccc}
\hline \hline Date & coefficient & p-value \\
\hline $2016-01-14$ & -4.68 & 0 \\
$2016-03-15$ & -4.43 & 0.01 \\
$2016-03-29$ & -3.82 & 0.01 \\
$2016-07-26$ & -4.23 & 0.01 \\
$2016-12-15$ & -4.6 & 0.01 \\
$2017-01-27$ & -4.13 & 0.01 \\
$2017-06-13$ & -4.28 & 0.01 \\
$2017-06-27$ & -2.96 & 0.11 \\
$2017-07-10$ & -4.15 & 0.01 \\
$2017-12-18$ & -4.28 & 0.01 \\
$2017-12-20$ & -4.54 & 0 \\
$2017-12-21$ & -4.25 & 0.01 \\
$2018-01-10$ & -4.22 & 0.01 \\
$2018-06-11$ & -4.11 & 0.01 \\
$2018-06-12$ & -4.12 & 0.01 \\
$2018-06-21$ & -4.24 & 0.01 \\
$2018-07-03$ & -4.28 & 0.01 \\
$2018-07-05$ & -4.35 & 0.01 \\
$2018-09-26$ & -4.24 & 0.01 \\
$2018-12-10$ & -4.26 & 0.01 \\
$2018-12-13$ & -4.55 & 0.01 \\
$2018-12-14$ & -4 & 0.01 \\
$2019-03-18$ & -4.08 & 0.01 \\
$2019-03-29$ & -4.25 & 0.01 \\
$2019-05-27$ & -4.24 & 0.01 \\
$2019-06-28$ & -4.26 & 0.01 \\
$2019-07-23$ & -4.25 & 0.01 \\
\hline & &
\end{tabular}

Notes: This robustness tests starts from the baseline regression on CDS spreads, and consists in reestimating it removing one by one the 27 country level CCyB increases for which at least one bank is concerned in the baseline specification. The second and third columns report the point estimate and p-value for the coefficient of $\triangle C C y B$

Table 12: Robustness to removing one by one the 27 country level CCyB increases 


\section{D.7 Other robustness tests}

\begin{tabular}{lccc}
\hline \hline & \multicolumn{3}{c}{ Dependent variable: $\Delta C D S$} \\
\cline { 2 - 4 } & Retropolated & Zero announcement & Zero domestic announcement \\
& $(1)$ & $(2)$ & $(3)$ \\
\hline$\Delta$ CCYB & $-3.117^{* *}$ & \\
Announcement & $(1.426)$ & & \\
& & -0.053 & 0.141 \\
Domestic announcement & & $(0.092)$ & $(0.274)$ \\
& & & 25,167 \\
Observations & 39,246 & 25,167 & 107 \\
No. country shocks & 33 & 238 & 309 \\
No. bank shocks & 189 & 6234 & 0.179 \\
$\mathrm{R}^{2}$ & 0.256 & 0.179 & 0.177 \\
Adjusted $\mathrm{R}^{2}$ & 0.255 & 0.177 & \\
\hline \hline
\end{tabular}

Notes: Retropolated includes shocks that occurred prior to 2016 using retropolated country exposures to estimate bank specific shocks. Zero announcement regresses CDS spread variations on a dummy taking value 1 on all dates when some national authority announced an absence of change in CCyB rate. Zero domestic announcement regresses CDS spread variations on a dummy taking value 1 for all banks of a country when that country announces an absence of change in CCyB rate. Robust standard errors are shown in brackets. ${ }^{*} \mathrm{p}<0.1 ;{ }^{* *} \mathrm{p}<0.05 ;{ }^{* * *} \mathrm{p}<0.01$.

Table 13: Other robustness tests

\section{D.8 Placebo test}

\begin{tabular}{lc}
\hline \hline & Dependent variable: $\Delta C D S$ \\
\cline { 2 - 2 } & \\
\hline Placebo shock & -0.003 \\
& $(0.004)$ \\
\hline Observations & 84,438 \\
$\mathrm{R}^{2}$ & 0.426 \\
Adjusted $\mathrm{R}^{2}$ & 0.425 \\
\hline \hline
\end{tabular}

Notes: Placebo shocks are randomly drawn without replacement in the pooled time series of $\mathrm{CCyB}$ shocks. ${ }^{*} \mathrm{p}<0.1 ;{ }^{* *} \mathrm{p}<0.05 ;{ }^{* * *} \mathrm{p}<0.01$.

Table 14: Placebo test 


\section{D.9 Robustness of stock return results}

\begin{tabular}{lcccccc}
\hline \hline & \multicolumn{5}{c}{ Dependent variable: Stock return } \\
\cline { 2 - 6 } & Baseline & Large shock & Baseline & Large shock & CDS sample & CDS sample \\
& $(1)$ & $(2)$ & $(3)$ & $(4)$ & $(5)$ & $(6)$ \\
\hline CCYB & 0.004 & 0.005 & & & 0.007 & \\
& $(0.007)$ & $(0.006)$ & & & $(0.014)$ & -0.001 \\
Dummy & & & -0.0004 & 0.001 & & $(0.002)$ \\
\hline Observations & 51,618 & 51,190 & 51,618 & 51,190 & 25,316 & 25,316 \\
No. country shocks & 28 & 19 & 28 & 19 & 27 & 27 \\
No. bank shocks & 275 & 59 & 275 & 59 & 171 & 171 \\
$\mathrm{R}^{2}$ & 0.437 & 0.438 & 0.437 & 0.438 & 0.536 & 0.536 \\
Adjusted R ${ }^{2}$ & 0.436 & 0.437 & 0.436 & 0.437 & 0.535 & 0.535 \\
\hline \hline
\end{tabular}

Notes: Dummy takes value 1 whenever there is a positive CCYB shock (Baseline) or a CCYB shock of value in the fourth quartile (Large shocks). The CDS sample regressions estimate the stock return equation on points of the panel when CDS spreads are defined to allow for comparisons. All estimations are on a $(0,1)$ event window. Robust standard errors are shown in brackets. ${ }^{*} \mathrm{p}<0.1 ;{ }^{* *} \mathrm{p}<0.05 ;{ }^{* * *} \mathrm{p}<0.01$

Table 15: Robustness of stock return results 